\title{
Effects of hypoxia on epididymal sperm parameters and protective role of ibuprofen and melatonin
}

\author{
Álvaro Vargas ${ }^{1}$, Eduardo Bustos-Obregón² and Ricardo Hartley² \\ 'Santo Tomás University, Veterinary Medical School, Santiago, Chile. \\ ${ }^{2}$ Laboratory of Biology of Reproduction. Institute of Biomedical Sciences. Medical School. University of Chile. Santiago, Chile.
}

\begin{abstract}
Hypobaric hypoxia is of interest due to an increase of human populations working at high altitude. Testicular damage is related to the physiological response (neoangiogenesis) to increased intrascrotal blood flow as temperature rises. Hypoxia is a stress factor with overproduction of reactive oxygen species (ROS). The effect of hypoxia in mice reproductive parameters is analyzed. Animals were exposed to simulated hypoxia of 4,200 meters above sea level (m.a.s.1.) in a chamber for 33.2 days, both to continuous $(\mathrm{HH})$ or intermittent hypoxia (HI) with an intermittency period of 4 days hypoxia / 4 days normoxia (500 m.a.s.1.).

The anti-inflammatory drug Ibuprofen was administered to a group of mice to control vasodilation and increased blood flow. Melatonin was administered to another group of mice as a potent ROS scavenger. Animals in both $\mathrm{HH}$ and HI exposure were compared to normoxic nontreated controls.

There was a hematological response in hypoxia, with an increase in hematocrit and reticulocytosis. There was also increased teratozoospermia. This damage was more pronounced in $\mathrm{HH}$ than $\mathrm{HI}$, suggesting that alternating normoxic periods permits compensation for the effects of hypoxia.

In both hypoxia systems, the level of lipoperoxidation and the instability of DNA increased. In HH, there was a reduction of teratozoospermia in melatonin-treated mice.

Ibuprofen presented a protective effect on the same parameters as melatonin with both HI and HH. The quality of sperm DNA, fragmentation, unpacking and DNA stability diminished.

In conclusion, reproductive damage elicited by $\mathrm{HH}$ or $\mathrm{HI}$ was partially ameliorated by simultaneous treatment with antiflogistic and/or antioxidant agents.
\end{abstract}

Key words: epididymal sperm; mouse; ibuprofen; melatonin

\section{INTRODUCTION}

Hypobaric Hypoxia

Atmospheric pressure, which is $760 \mathrm{~mm} \mathrm{Hg}$ at sea level, decreases with altitude, as does the partial pressure of its components $\left(\mathrm{O}_{2}, \mathrm{~N}_{2}, \mathrm{CO}_{2}\right)$. Oxygen is $21 \%$ of atmospheric gases. When it decreases its partial pressure in the alveolar air, saturation of hemoglobin and blood oxygen content and transport diminish, and therefore the supply of oxygen to tissues drops (Fouillot and Barrault, 1982).

It has been reported that hypobaric hypoxia is responsible for altered male reproductive function. Because more men are working at high altitudes, the effects of hypobaric hypoxia on spermatogenesis has became of interest during the last 20 years. The mechanism of action concerning fertility has not been clearly established, requiring further studies, particularly on intermittent hypoxia, which affects workers in the copper mining industry in northern Chile. This is a new epidemiological situation, as pointed out by Siqués and Brito (2001).

Testicular damage due to hypoxia

Environmental conditions reduce reproductive functions in men recently arrived to high altitudes, but it is not clear if fertility is also compromised in natives inhabiting high altitudes (Vitzthum and Wiley, 2003). UNESCO defines high altitude as over 3,000 meters above sea level (m.a.s.l.). Hypoxia compromises fertility in man (Okumura et al., 2003) and in other mammals (Bustos-Obregón and Celis, 1982). It also exerts an inhibitory effect on dividing cell populations (Kim and Han, 1969; Check et al., 1969). Therefore, the spermatogenic process is probably affected by hypoxia.

The body reacts to hypoxia with adaptive responses, such as angiogenesis and vasodilation, thus increasing blood supply to tissues, compensating for the lack of oxygen. However, this response induces spermatogenic damage due to the increase of $1.5^{\circ} \mathrm{C}$ in testicular temperature (Farias et al., 2005). Considering that non-steroidal anti-inflammatory agents are antiangiogenic, they might reduce testicular damage caused by hypoxia.

Another physiological reaction to hypoxia is the increase of reactive oxygen species (ROS). Since melatonin is a potent antioxidant, scavenger of oxygen-free radicals and highly specific controller of lipid peroxidation, it is feasible that its administration protects the testis against hypoxic damage.

Adaptive physiological responses to hypoxia

Due to the great distance of oxygen diffusion from blood vessels to the luminal region of the seminiferous tubules, 
this area is hypoxic compared to the basal region. The high proliferative activity of the seminiferous epithelium suggests high oxygen consumption. Hence, the expression of glycolitic enzymes must be related to metabolic adaptation to hypoxia. Many reproductive events, such as sperm capacitation, mobility changes, acrosomic reaction and fertilization, are dependent on anaerobic glycolisis and can occur under anaerobiosis (Fraser and Quinn, 1981). However, the exact molecular events involved are not fully understood (Marti et al., 2002).

The organism responds to the lack of oxygen by rapid or delayed mechanisms

One type of rapid response to lack of oxygen is vascular dilation, leading to an increase in blood flow. This reaction is regulated by nitric oxide (NO), cyclic GMP, and protein kinase G (Lodish et al., 2005). Nitric oxide is a free radical, produced by the nitric synthase oxide enzyme (NOS-2) in the amino acid L-arginine. NOS-2 is produced by cells stimulated by endotoxins or cytokines. NO penetrates the target cells (endotheliocytes), activating a soluble enzyme guanylyl cyclase, which synthesises cGMP from GTP, thus modulating the activity of protein kinase $G$ in the vascular endothelium, producing vasodilation (Murad, 2006).

Ibuprofen

Non-steroidal anti-inflammatory agents are antiangiogenic, also diminishing vasodilation, blocking the activity of HIF$1 \alpha$, and decreasing expression of VEGF (Sanjeewani et al., 2003). Ibuprofen was used to evaluate the putative protective role of testis exposed to $\mathrm{HH}$ or $\mathrm{HI}$, by reducing the increased intrascrotal temperature due to VEGF-induced angiogenesis.

Hypoxia and production of reactive oxygen species

Hypoxia stimulates ROS production from mitochondria, thus eliciting cell-oxidative stress due to excessive presence of prooxidative molecules.

Under normal conditions, there is a balance between pro- and anti- oxidative molecules and the antioxidants in the cytoplasm. (Garrido et al., 2004). When pro-oxidation predominates, there is oxidative damage in biomolecules such as proteins, carbohydrates, lipids and nucleic acids (Pande and Flora, 2002; El-Missiry, 2000; Ercal et al., 1996). In the sperm, antioxidative systems are present in the cytoplasm and seminal plasma, preventing accumulation of ROS and preserving sperm function. Excessive ROS production is associated with impaired sperm function (Wang et al., 2003).

The plasmatic cell membrane may be damaged by ROS, due to its high content in polyunsaturated lipid acids that undergo lipid peroxidation. Structural DNA damage and cell death may follow (El-Sokkary et al., 2003; Bhardwaj et al., 2000, Koksal et al., 2003).

Antioxidative molecules are scarce in sperm cells because of their small cytoplasm, and therefore, addition of exogenous antioxidant agents may be relevant to prevent hypoxic oxidative damage (Garrido et al., 2004; Golden et al., 1999).
Melatonin

Numerous reports have documented a protective role of melatonin in different models of oxidative cellular stress (HiroAki and Hai-Wang, 1996). Melatonin significantly reduces ROS damage to tissues in vivo and in vitro. It also protects nuclear DNA and nuclear and lipid cell membranes from ROS attack (Lena and Subramanian, 2003; El-Missiry, 2000).

Melatonin circulates freely in all subcellular compartments (Lena and Subramanian, 2003; Hiro-Aki and Hai-Wang, 1996). It also crosses morphophysiological barriers, such as the blood-testis barrier and stimulates the activity of enzymes that metabolize ROS (El-Sokkary et al., 2003).

This investigation analyzes sperm damage in mice exposed to $\mathrm{HH}$ and $\mathrm{HI}$ in a hypobaric chamber, compared to controls (500 m.a.s.l., the altitude of Santiago, Chile, during a full spermatogenic cycle (33.2 days). The protective values of ibuprofen as an inflammatory and melatonin as an antioxidant were evaluated

Hematocrit and reticulocytosis were determined to evaluate the response of mice to both hypoxic systems.

\section{METHODS}

Experimental outline

Seventy-two mice (three months old) from the animal facility of the University of Chile Medical School were used. They were kept at a temperature of $22 \pm 2^{\circ} \mathrm{C}$, with a light regimen of $12 \mathrm{l} / 12 \mathrm{~d}$ hs, and fed commercial pellets and water ad libitum. Epididymal sperm parameters of mice exposed to simulated hypoxia in a hypobaric chamber set at 4200 m.a.s.l. were analyzed. One group (24 mice) was exposed to continuous hypobaric hypoxia $(\mathrm{HH})$ for a full spermatogenic cycle. The second group was exposed to intermittent hypoxia (4 days at altitude $x / 4$ days at Santiago altitude), also for 33.2 days, and the third group was kept in normoxia (control) at 500 m.a.s.l. for 33.2 days. Each group was divided into 3 subgroups of 8 mice (8 were intraperitoneally injected with ibuprofen $(20 \mathrm{mg} /$ $\mathrm{Kg}$. bw), every 4 days; 8 received melatonin in the drinking water $(10 \mathrm{mg} / \mathrm{Kg} . \mathrm{bw})$, and 8 had no treatment (control) (Fig 1).

All experimental procedures were in accordance with the Regulations established by the Faculty's Ethical Committee.

Hematological parameters

The mice were weighed the first day and on day 33.2, when testicular and epididymal weights were also measured after euthanasia by injection of Ketamine. Blood was obtained by cardiac puncture with a heparinized syringe and used to measure Hematocrit and obtain a smear to count reticulocytes after May Grünwald-Giemsa staining.

Epididymal sperm counts

The cauda epidydimal were weighed and macerated in $5 \mathrm{ml}$ of PBS, and left at $4^{\circ} \mathrm{C}$ for two hours. Thereafter, the suspension was filtered by double gauze, and the cell count was performed using a Neubauer chamber. The sample was then washed twice with PBS, centrifuged at $800 \mathrm{~g}$ for 10 minutes, and adjusted to a concentration of 10 millon/ml PBS to perform the other sperm studies (Vigil and Bustos-Obregón, 1985). 
Sperm morphology

A drop of washed spermatozoa was dried on a glass slide and fixed in $70 \%$ ethanol for one minute, ready to be stained with Harris hematoxylin for 10 seconds. It was then washed under tap water for 10 minutes and in distilled water for 1 minute and then stained in aqueous $1 \%$ eosin for 5 minutes. Finally, the slides were washed with distilled water, and observed under a light microscope at 1000x, describing teratozoospermia according to Vigil and Bustos-Obregón (1985).

Chromatin packing

The chromatin-packing test evaluates chromatin packing when the cells are exposed to strong reducing agents, such as sodium thioglycolate (0.4 $\left.\mathrm{mol} \mathrm{L}^{-1}, \mathrm{pH} 9.0\right)$, following the protocol described by Fornés and Bustos-Obregón (1993). Sperm nuclei with fewer disulphide bridges will swell and be counted as decondensed after glutaraldehyde fixation and aniline blue staining when observed under 1000x in the microscope if their volume exceeds by that of the non-treated control sperm nuclei by $50 \%$.

DNA stability

DNA denaturation was analyzed by epifluorescent observation after staining with acridine orange. Sperm fluorescence after thermal denaturation is red when DNA is denatured (single strand, metachromatic reaction), or yellow-green when DNA is native (Tejada et al., 1984).

\section{ROS estimation}

Cauda epidydimal spermatozoa were used to measure the degree of lipid peroxidation using the thiobarbituric acid reactive substances assay (TBARS) and malondialdehyde (MDA). TBARS reactive molecules are expressed as nmol TBARS $/ 10^{6}$ sperm, read in a spectrophotometer set at $535 \mathrm{~nm}$ (Aitken et al, 1989).

\section{Statistical evaluation}

All results were expressed as mean \pm standard deviations. Statistical analysis employed a non-parametric KruskalWallis ANOVA test and the Dunn multiple comparison test to determine if there were significant differences in the results obtained between experimental and control groups.

\section{RESULTS}

Effects of HI and HH versus Normoxia

Hematological parameters:

- Hematocrit: The percentage of microhematocryte increased significantly in both hypoxia systems (Table I).

- Reticulocytes: The percentage of reticulocytes increased significantly in both hypoxia systems (Table I).

Epididymal parameters

- The weight of epidydimal cauda significantly decreased in HI. There was also a non-significant decrease in the case of $\mathrm{HH}$ (Table I).

- Epidydimal sperm count decreased significantly in $\mathrm{HH}$. The same occurred with HI, although not significantly compared to the control group (Table I).

- Sperm morphology: With both HI and HH, the percentage of normal sperm decreased significantly. In control animals, there were some gametes with tail anomalies. In contrast, in both $\mathrm{HI}$ and $\mathrm{HH}$, the predominant anomalies were head malformations (Table I).

- Chromatin unpacking: The percentage of chromatin decondensation increased significantly in both $\mathrm{HI}$ and $\mathrm{HH}$ (Table I; Figs. 3 and 4).

- DNA stability: In $\mathrm{HH}$ there was a significant increase of sperm with single-stranded DNA (Table I; Fig. 5 and $6)$. Figure 5 shows green fluorescence revealing nondenatured, double-stranded DNA. Figure 6 shows metachromatic staining revealing single-stranded DNA.

Table I

Effects of $\mathrm{HI}$ and $\mathrm{HIH}$ on mice reproductive parameters

\begin{tabular}{|c|c|c|c|c|}
\hline PARAMETER & $\mathrm{Nx}$ & HI & $\mathrm{HH}$ & Significance \\
\hline Hematocrit (\%) & 34.5 & 45.8 * & $50.2 * *$ & $\begin{array}{l}{ }^{*} \mathrm{p}<0.05 \\
{ }^{* *} \mathrm{p}<0.01\end{array}$ \\
\hline Reticulocyte (\%) & 2.28 & $27.1 * * *$ & $29.3 * * *$ & ${ }^{* * *} \mathrm{p}<0.001$ \\
\hline Cauda Epididymal Weight (grs) & 0.054 & $0.038^{* *}$ & 0.042 & ${ }^{* *} \mathrm{p}<0.01$ \\
\hline Epidydimal Sperm Count ( $10^{6}$ sperm / mg epididymis) & 0.612 & 0.419 & $0.219 * *$ & ${ }^{* *} \mathrm{p}<0.01$ \\
\hline Sperm Morphology (\%) & 85.8 & $64^{* *}$ & $53.6 * * *$ & $\begin{array}{rl}* * & p<0.01 \\
* * * & p<0.001\end{array}$ \\
\hline Chromatin Unpacking ( $\%$ of decondensed spermatozoa) & 13.1 & 36.5 * & 37 * & ${ }^{*} \mathrm{p}<0.05$ \\
\hline DNA Stability (\%) & 1.8 & $9.5 * *$ & $22.25 * * *$ & $\begin{array}{rl}* * & p<0.01 \\
& <<0 \\
p & <0.001\end{array}$ \\
\hline Sperm Lipoperoxidation (nmol/tbars) & 39.55 & $88.48^{* * *}$ & 58.01 & ${ }^{* * *} \mathrm{p}<0.001$ \\
\hline
\end{tabular}


- Sperm lipoperoxidation: This test correlates directly to the production of ROS. Lipid peroxidation increased significantly in the $\mathrm{HI}$ group and very slightly in $\mathrm{HH}$ (Table I).

\section{EVALUATION OF IBUPROFEN AND MELATONIN EFFECT IN HI AND HH}

Hematological parameters

Ibufrofen and melatonin did not change the hematological response elicited from the two hypoxic situations (Table II).

Sperm parameters

- Sperm count: Melatonin did not change the sperm counts. Ibuprofen significantly improved the count for both $\mathrm{HI}$ and $\mathrm{HH}$ (Tables II and III).

- Sperm morphology: Melatonin significantly decreased teratozoospermia in $\mathrm{HH}$. In $\mathrm{HI}$, there was no significant difference with non-treated mice. Ibuprofen did not show any effect on HH nor on HI (Tables II and III).

- Chromatin unpacking: Ibuprofen significantly decreased the percentage of chromatin decondensed sperm, in both $\mathrm{HI}$ and $\mathrm{HH}$. In this parameter, Melatonin did not differ from the controls (Tables II and III).

- DNA stability: Both Melatonin and Ibuprofen significantly reduced the percentage of unstable DNA in $\mathrm{HI}$ and $\mathrm{HH}$ (Tables II and III).

- Sperm lipoperoxidation: Sperm lipid peroxidation decreased significantly in the groups treated with melatonin in both HI and HH. Ibuprofen did not show differences with the control groups. (Tables II and III).

\section{DISCUSSION}

Published data confirm that hypobaric hypoxia is responsible for altering reproductive function in humans and animals (Bustos-Obregón and Celis, 1982), but also for reducing the number of offspring born at high altitude (Cikutovic et al, 2009), and mostly damaging the male factor (Donayre, 1966). Many other publications are concerned with fertility compromise at high altitude (Zamudio et al., 1995; Niermeyer 1999; Beall 2000; Moore et al, 2000; Crognier et al., 2002; Moore, 2003; Vitzthum and Wiley 2003; Dang et al., 2006). Acute simulated hypobaric hypoxia at extremely high altitudes results in damage to all testicular cells, including spermatogenic and somatic elements (Sertoli and Leydig cells) (Shevantaeva and Kosyuga, 2006). Other authors associate fertility problems to labour schedules (Xu et al., 1994; Bisanti et al., 1996; Costa, 1996; Kogi, 1996; Monk et al., 1996; Nurmimen, 1998; Scott, 2000; Zhu et al., 2003; Harma, 2006; Berger and Hobbs, 2006). Working schedules represent a biological, mental and social stress that could alter health, well-being, and performance of the workers in this environment. In consequence, the analysis of reproductive alterations at high altitude is very complex.

Hematological parameters

Hematocrit in animals exposed to both $\mathrm{HI}$ and $\mathrm{HH}$ for 33.2 days, increases significantly compared to controls, due to the physiological response to lower oxygen availability. Red blood cell production increases to maximize oxygen transport to tissues. Similar results were seen in $4 \times 4 \mathrm{HI}$ exposure mouse model in our laboratory (Bustos-Obregón et al., 2006). This response is not modified by melatonin or ibuprofen.

Another observation in rats exposed to $\mathrm{HH}$ or $\mathrm{HI}$ (intermittency of $4 \times 4$ days), for 33.2 days in a hypobaric chamber simulating 4200 m.a.s.l., reported a significant increase in the mass of red blood cells (Farías et al., 2005). This result agrees with data showing that slow adaptation to low oxygen levels, triggered by erythropoietin secreted by the kidney, induces red blood cell production (Lodish et al., 2005).

The increase in reticulocytes, in $\mathrm{HI}$ and $\mathrm{HH}$ demonstrates accelerated red blood cell production in exposed animals. These conditions are not modified by melatonin or ibuprofen.

Sperm parameters

The sperm count decreases significantly in $\mathrm{HH}$, which might indicate that hypoxia provokes alterations in the process of sperm differentiation (Clermont, 1972). The increased temperature in the testis may play a role in the oxidative stress evidenced in the testes (Santoro and Romeo, 2001) and semen (Hendin et al., 1999; Smith et al., 2006) of varicocele patients, as well as chryptorchid patients (Ahotupa and Huhtaniemi, 1992; Peltola et al., 1995; Misro et al., 2005).

Melatonin does not modify sperm count, which is ameliorated significantly by ibuprofen, even reaching control values. This is probably due to the reduction in neoformation of capillaries in the testicular interstitium.

Both $\mathrm{HI}$ and $\mathrm{HH}$ provoke high teratozoospermia, highlighting the effect of hypoxia in spermatid differentiation, related to excessive ROS production, since melatonin significantly reduces sperm malformations, whereas ibuprofen did not show this effect.

Chronic hypoxia causes reversible impairment of male fertility in humans. Normal seminograms are recovered after 6 months, following exposures to 2000 to 6000 m.a.s.l. for periods of 26 days (Verrati et al., 2008).

Damage to seminiferous epithelium and cauda epididimal spermatozoa in mice were reported by Bustos-Obregón et al (2006).

Epididymal sperm count is reduced already at 7 days after exposure to 4340 m.a.s.l. (Cerro de Pasco, Perú), probably by affecting the onset of meiosis and spermiation (Gasco et al., 2003).

Sperm damage due to short (4 days) exposure to the same altitude can be prevented by cyproheptadine administration to rats (Gonzales et al., 1990).

Sperm lipid peroxidation and ROS production are directly proportional. Both conditions have been detected in varicocele patients (Agarwal et al., 2003). The same happens to mice exposed to HI. Exposure to $\mathrm{HH}$ does not differ to the parameters observed in normoxia, implying an adaptation of the testis after long intervals of hypoxia.

\section{DNA sperm parameters}

As commented above, oxidative stress plays a role in male infertility (Agarwal et al., 2003). Increased ROS production is associated with loss of sperm function and alterations of fertilizing ability of the male gamete (Moustafa et al., 2004; Wang et al., 2003). Sperm genomic integrity can be also affected 
Table II

Melatonin and ibuprofen effects on reproductive parameters of mice exposed to $\mathrm{HI}$

\begin{tabular}{|c|c|c|c|c|}
\hline INTERMITTENT HYPOXIA & Control(HI) & Melatonin & Ibuprofen & Significance \\
\hline Hematocrit $(\%)$ & 45.8 & 48.2 & 44.4 & Not significant \\
\hline Reticulocyte (\%) & 27.1 & 30.7 & 23.1 & Not significant \\
\hline Cauda Epididymal Weight (grs) & 0.037 & 0.043 & 0.044 & Not significant \\
\hline Epididymal Sperm Count (106 sperm/mg epididymis) & 0.41 & 0.43 & $0.62 * * *$ & $* * * \mathrm{p}<0.001$ \\
\hline Sperm Morphology (\%) & 64 & 70.2 & 71 & Not significant \\
\hline Chromatin Unpacking ( $\%$ of decondensed spermatozoa) & 36.5 & 32.5 & $12.37^{* * *}$ & $* * * p<0.001$ \\
\hline DNA Stability $(\%)$ & 9.5 & $2.6 * *$ & $2.3^{* *}$ & ${ }^{* *} \mathrm{p}<0.01$ \\
\hline Sperm Lipoperoxidation (nmol/tbars) & 8.4 & 5.9 * & 8.1 & ${ }^{*} \mathrm{p}<0.05$ \\
\hline
\end{tabular}

Table III

Melatonin and ibuprofen effects on reproductive parameters of mice exposed to $\mathrm{HIH}$

\begin{tabular}{|c|c|c|c|c|}
\hline CONTINUOUS HYPOXIA & Control (HH) & Melatonin & Ibuprofen & Significance \\
\hline Hematocrit (\%) & 50.25 & 50.78 & 48.4 & Not significant \\
\hline Reticulocyte (\%) & 29.37 & 31 & 27.75 & Not significant \\
\hline Cauda Epididymal Weight (grs) & 0.041 & 0.042 & 0.042 & Not significant \\
\hline Epididymal Sperm Count ( $10^{6}$ sperm / mg epididymis) & 37 & 22.01 & $13.25 * * *$ & $* * * p<0.001$ \\
\hline Sperm Morphology (\%) & 22.25 & 15.5 ** & $12.3 * *$ & ${ }^{* *} \mathrm{p}<0.01$ \\
\hline Chromatin Unpacking (\% of decondensed spermatozoa) & 5.01 & $2.07 * * *$ & 4.51 & $* * * \mathrm{p}<0.001$ \\
\hline DNA Stability $(\%)$ & 0.219 & 0.360 & $0.611^{* * *}$ & ${ }^{* * *} \mathrm{p}<0.001$ \\
\hline Sperm Lipoperoxidation (nmol/tbars) & 53.62 & $78.37^{* * *}$ & 72.25 & ${ }^{* * *} \mathrm{p}<0.001$ \\
\hline
\end{tabular}

(Shen et al., 1999). Evaluation of the effects of hypoxia on DNA stability confirms this idea. In HI, there is an increase of chromatin unpacking and DNA instability. Melatonin significantly reduces this damage, which demonstrates that excessive ROS produced in hypoxia alters cell membranes, leading eventually to cell death (Koksal et al., 2003). Ibuprofen protects in both $\mathrm{HI}$ and $\mathrm{HH}$ since the damage observed in functional sperm parameters decreased in the treated mice. This effect is due to the antiangiogenic action of ibuprofen, so that better sperm DNA quality is observed in these mice.

The control of ROS and scrotal temperature seems a valuable tool to protect spermatogenesis from the noxious effects of hypoxia, and probably in cases of damage by the numerous testicular toxicants present in our increasingly polluted world.

\section{CONCLUSIONS}

The exposure to continuous and intermittent hypoxia alters the male mice reproductive system. Greater testicular damage was observed under continuous hypoxia. With intermittent hypoxia, lesions were less important, suggesting that cycles of normoxia compensate the effects on the testicle.

Intermittent hypoxia produces an increased haematological response, increasing the hematocrit and reticulocyte percentages, raising the degree of lipoperoxidation and teratozoospermia and reducing the quality of sperm DNA.

Continuous hypoxia generates a hematologic response, elevating the hematocrit and reticulocyte percentages, and reducing the sperm count, increasing teratozoospermia and reducing the quality of sperm DNA.

Melatonin reduces the degree of lipid peroxidation and improves the stability of sperm DNA under intermittent hypoxia. Additionally, under continuous hypoxia it reduces morphological alterations on spermatozoa.

Ibuprofen improves the epididymal sperm count and increases the quality of sperm DNA.

The use of anti-inflammatory drugs and antioxidant agents seem to be a useful tool in the control of damage to male reproduction produced as a result of hypoxia. 


\section{REFERENCES}

AGARWAL A, SALEH RA, BEDAIWY MA. (2003) Role of reactive oxygen species in the pathophysiology of human reproduction. Fertil Steril. 79; $829-43$.

AHOTUPA M, HUHTANIEMI I. (1992) Impaired detoxification of reactive oxygen and consequent oxidative stress in experimentally cryptorchid rat testis. Biol Reprod. 46;1114-1118.

AITKEN RJ, CLARKSON JS AND FISHEL C. (1989) Generation of reactive oxygen species, lipid peroxidauon and human sperm function Biol Reprod. 41;183-197.

BEALL CM. (2000) Tibetan and andean contrast in adaptation to highaltitude hypoxia. Adv Exp Med Biol. 475;63-74.

BERGER AM, HOBBS BB. (2006) Impact of shift work on the health and safety of nurses and patients. Clin J Oncol Nurs.10;465-71.

BHARDWAJ A, VERMA A, MAJUMDAR S, KHANDUJA L.(2000) Status of vitamin $\mathrm{E}$ and reduced glutathione in semen of oligozoospermic and azoospermic patients. Asian Journal Andrology. 2;225 - 228.

BISANTI L, OLSEN J, BASSO O, THONNEAU P, KARMAUS W. (1996) Shift work and sub fecundity: A European multicenter study. European Study Group Infertility and sub fecundity. J Occup Environ Med. $38 ; 352-8$.

BUSTOS-OBREGÓN E, CELIS R. (1982) Efecto de la hipoxia en la reproducción de mamíferos. Función testicular postexposición en cámara hipobárica. En el Hombre y los Ecosistemas de Montaña (MAB6), Montevideo: Ed. UNESCO-ROSTLAC. pp. 37-64.

BUSTOS-OBREGÓN E, ESVEILE C, CONTRERAS J, MAURER I, SARABIA L. (2006) Effects of chronic simulated hypobaric hypoxia on mouse spermatogenesis. Int. J. Morphol. 24;481-488

CHECK DB, GRAYSTONE JE, ROWE RD. (1969) Hipoxia and malnutrition in newborn rats: effects on RNA, DNA and protein in tissues. Am. J. Physiol. 217;642.

CIKUTOVIC M, FUENTES N, BUSTOS-OBREGÓN E. (2009) Effect of intermittent hypoxia on the reproduction of rats exposed to high altitude in the chilean altiplano. High Alt.Med.Biol.10;357-363.

CLERMONT Y. (1972) Kinetics of spermatogenesis in mammals: seminiferous epithelium cycle and spermatogonial renewal. Physiol Rev January.52;198-236.

COSTA G. (1996) The impact of shift and night work on health. Appl Ergon. $27 ; 9-16$.

CROGNIER E, VILLENA M, VARGAS E. (2002) Reproduction in high altitude Aymara: Physiological stress and fertility planning. J Biosoc Sci. 34;463-73.

DANG SN, YAN H, ZENG LX. (2006) Epidemiological features of spontaneous abortion among reproductive Tibetan woman living at high altitudes areas. Zhonghua Liu Xing Bing Xue Za Zhi. 27;212-6.

DONAYRE J. (1966) Population growth and fertility at high altitude. In life at high altitude, scientific publication $\mathrm{N}^{\circ} 140$. Washington DC. Panamerican health organization. 74. In: Heat D, Williams DR. High altitude Medicine and Pathology, 1995. Oxford University Press Ed.

EL-MISSIRY M. (2000) Prophylactic effect of melatonin on lead-induced inhibition of heme biosynthesis and deterioration of antioxidants systems in male rats. J. Biochem. Mol. Tox. 14;57-62.

EL-SOKKARY GH, KAMEL ES, REITER RJ. (2003) Prophylactic effect of melatonin in reducing lead-induced neurotoxicity in the rat. Cellular and Molecular Biology Letters. 8; 461-470.

ERCAL N, TREERATPHAN P, HAMMOND TC, MATTHEWS RH, GRANNEMANN NH, SPITZ DR. (1996) In vivo indices of oxidative stress in lead-exposed c57bl/6 mice are reduced by treatment with meso-2,3-dimercaptosuccinic acid or N-acetylcysteine. Free Radicals Biology and Medicine. 21;157 - 161 .

FARÍAS JG, BUSTOS-OBREGÓN E, REYES JG. (2005) Increase in testicular temperature and vascularization induced by hypobaric hypoxia in rats. J. Androl. 26; 693-7.

FORNÉS M, BUSTOS-OBREGÓN E. (1994) Study of nuclear decondensation of the rat spermatozoa by reducing epididymal transit. Andrologia. $26 ; 87-92$.

FOUILLOT JO, BARRAULT D (1982). Fisiopatología y Altitud. Rev. Tribuna Médica LII 8); 9-17.

FRASER LR, QUINN PJ. (1981). A glycolytic product is obligatory for initiation of the sperm acrosome reaction and whiplash motility required for fertilization in the mouse. J Reprod Fertil. 61;25-35

GARRIDO N, MOSAEGUER M, SIMON C, PELLICER A. Y REMOHI J. (2004) Pro-oxidative and anti-oxidative imbalance in human semen and its relation with male fertility. Asian Journal Andrology. 6; 59- 65 .
GASCO M, RUBIO J, CHUNG A, VILLEGAS L, GONZALES GF (2003). Effect of high altitude exposure on spermatogenesis and epididymal sperm count in male rats. Andrologia. 35;368-374

GONZALES GF, RODRÍGUEZ L, VALERA J, SANDOVAL E, GARCÍAHJARLES M. (1990). Prevention of high altitude-induced testicular disturbances by previous treatment with cyproheptadine in male rats. Arch Androl. 24;201-5.

GOLDEN AL, MOLINE JM, BAR-CHAMA N. (1999) Male reproduction and environmental and occupational exposures: a review of epidemiologic methods. Revista de Salud pública de México. 41;93 - 105.

HARMA M. (2006) Works hours in relation to work stress, recovery and health. Scand J Work Environ Health.32;502-14.

HENDIN BN, KOLETTIS PN, SHARMA RK, THOMAS AJ, AGARWAL A. (1999) Varicocele is associated with elevated spermatozoal reactive oxygen species production and diminished seminal plasma antioxidant capacity. J Urol.161;1831-1834.

HIRO-AKI Y, HAI-WANG T. (1996) Antagonistic effect of melatonin against cyanide-induced seizures and acute lethality in mice. Toxicology Letters. 87;19-24.

KIM JH, HAN S. (1969) Studies of hipoxia. V effects of anoxia on developing conective tisúes cells in rats. Anat. Rec. 165; 531.

KOGI K. (1996) Improving shift worker's health and tolerance to shift work: recent advances. Appl Ergon. 27;5-8.

KOKSAL IT, USTA M, ORHAN I, ABBASOGLU S, KADIOGLU A. (2003) Potential role of reactive oxygen species on testicular pathology associated with infertility. Asian Journal Andrology. 5;95 - 99.

LENA P, SUBRAMANIAN P. (2003) Evaluation of the antiperoxidative effects of melatonin in ammonium acetate-treated wistar rats. Polish Journal of Pharmacology. 55; 1031-1036.

LODISH H, BERK A, MATSUDAIRA P, KAISER C, KRIEGER M, SCOTT M, ZIPURSKY S, DARNELL. (2005) In: Molecular biology of the cell. 5th Edition. Chapter 15: Respuestas de las células frente a influencias ambientales. 619-620.

MARTI H, KATSCHINSKI DM, WAGNER KF, SCHÄFFER L, STIER B. (2002) Isoform-Specific expression of Hypoxia-Inducible Factor-1 during the late stages of mouse spermiogenesis. Mol Endocrinol. 16;234-43.

MISRO MM, CHAKI SP, GAUTAM DK. (2005) Germ cell death and their removal during initial stages of testicular ischemia and cryptorchidism:a comparative analysis. Indian J Exp Biol.43;1080-1087.

MONK TH, FOLKARD S, WEDDERBURN A. (1996) Maintaining safety and high performance on shift work. Appl Ergon. 27;17-23.

MOORE LG, ARMAZA F, VILLENA M, VARGAS E. (2000) Comparative aspect of high-altitude adaptation in human populations. Adv Exp Med Biol. 475;45-62.

MOORE LG. (2003) Fetal growth restriction and maternal oxygen transport during high altitude pregnancy. High Alt Med Biol. 4;141-56.

MOUSTAFA MH, SHARMA RK, THORNTON J, MASCHA E, ABDELHAFEZ MA, THOMAS AJ. (2004) Relationship between ROS production, apoptosis and DNA denaturation in spermatozoa from patients examined for infertility. Hum Reprod. 19;129-38.

MURAD F. (2006) Nitric oxide and cyclic GMP in cell signaling and drug development. N Engl J Med. 355;2003-11

NIERMEYER S. (1999) The pregnant altitude visitor. Adv Exp Med Biol. 474;65-77.

NURMINEN T. (1998) Shift work and reproductive health. Scand J Work Environ Health. 24;28-34.

OKUMURA A, FUSE H, KAWAUCHI Y, MIZUNO I, AKASHI T. (2003) Changes in male reproductive function after high altitude mountaineering. High Alt Med Biol. 4; 349-53.

PANDE M, FLORA SJS. (2002) Lead induced oxidative damage and its response to combined administration of -lipoic acid and succimers in rats. Toxicology 177;187-196.

PELTOLA V, HUHTANIEMI I, AHOTUPA M. (1995) Abdominal position of the rat testis is associated with high level of lipid peroxidation. Biol Reprod. 53;1146-1150

SANJEEWANI T, PHILIP J, COLEMAN N. (2003) Ibuprofen-mediated reduction of Hypoxia-inducible factors HIF-1 and HIF-2 in Prostate Cancer Cells. Clinical Cancer Research. 9;3150-3157.

SANTORO G, ROMEO C. (2001) Normal and varicocele testis in adolescents. Asian J Androl. 3;259-262.

SCOTT AJ. (2000) Shift work and health. Prim Care. 27;1057-79.

SHEN HM, CHIA SE, ONG CN. (1999) Evaluation of oxidative DNA damage in human sperm and its association with male infertility. J Androl. 20;718-23.

SHEVANTAEVA ON, KOSYUGA YI. (2006) Effect of acute hypobaric hypoxia on spermatogenesis and lactate concentration in testicular tissue of male albino rats. Bull Exp Biol Med.141;20-2. 
SIQUÉS P, BRITO J. (2001) Trabajo a gran altura intermitente: Nueva situación epidemiológica. Iquique. Eds Universidad Arturo Prat. 1-112.

SMITH R, KAUNE H, PARODI D, MADARIAGA M, RÍOS R, MORALES I, CASTRO A. (2006) Increased sperm DNA damage in patients with varicocele: relationship with seminal oxidative stress. Hum Reprod. 21;986-993

TEJADA R, CAMERON J, NORMAN A, MARIK J, FRIEDMAN S. (1984) A test the practical evaluation of male fertility by acridine orange $(\mathrm{AO})$ fluorescence. Fertility and Sterility. 42; 88-91.

VERRATTI V, BERARDINELLI F, DI GIULIO C, BOSCO G, CACCHIO M, PELLICCIOTTA M, NICOLAI M, MARTINOTTI S, TENAGLIA1 R. (2008). Evidence that chronic hypoxia causes reversible impairment on male fertility. Asian J Androl. 10;602-606.

VIGIL P, BUSTOS-OBREGÓN E. (1985) Alkylating agents and mouse spermatogenesis: Effects of a single dose of cyclophosphamide. Andrologia.17;276-82.
VITZTHUM VI, WILEY AS. (2003) The proximate determinants of fertility in populations exposed to chronic hypoxia. High Alt Med Biol. 4;125-39.

WANG $X$, SHARMA RK, SIKKA SC, THOMAS AJ, FALCONE T, AGARWAL A. (2003) Oxidative stress in associated with increased apoptosis leading to spermatozoa DNA damage in patients with male factor infertility. Fertility and Sterility. 80;531-535

XU X, DING M, LI B, CHRISTIANI DC. (1994) Association of rotating shift work with preterm births and low birth weight among never smoking women textile workers in china. Occup Environ Med. 51;470-74.

ZAMUDIO S, PALMER SK, DROMA T, STAMM E, COFFIN C, MOORE LG. (1995) Effect of altitude on uterine artery blood flow during normal pregnancy. J Appl Physiol. 79;7-14.

ZHU JL, HJOLLUND NH, BOGGILD H, OLSEN J. (2003) Shift work and sub fecundity: A causal link or an artefact? Occup Environ Med. 60;12-16. 
